original article, for Review of Palaeobotany and Palynology

Revision 1

\title{
A fossil coryphoid palm from the Paleocene of western Canada.
}

David R. Greenwood, Dept. of Biology, Brandon University, 270-18th Street, Brandon, MB, Canada, R7A 6A9.

Christopher K. West, Dept. of Geological Sciences, University of Saskatchewan, 114

Science Place, Saskatoon, SK, Canada, S7N 5E2. 


\section{Introduction}

Palms (Family Arecaceae, syn. 'Palmae') have a good North American Cretaceous to Cenozoic fossil record, including pollen, flowers, leaves, seeds, wood, and trunk molds (e.g., Berry, 1924; Brown, 1962; Mustoe and Gannaway, 1995; Harley and Baker, 2001; Harley, 2006; Dransfield et al., 2008; DeVore and Pigg, 2010; Manchester, 2014; Allen, 2015). They are iconic plant fossils, providing evidence of warm climates in the geological past well outside the current northern and southern limits of palms (e.g., Wing and Greenwood, 1993; Greenwood and Wing, 1995; Pole and Macphail, 1996; Archibald et al., 2014; Akhmetiev, 2015). Modern palms are in equilibrium with the current climate; their distribution and diversity as well as key traits such as leaf size are negatively correlated with temperature (Eiserhardt et al., 2011; Kissling et al., 2012a,b; Gödel et al., 2015). As such, palms are considered good indicators of past climate and of changes in temperature in particular (Wing and Greenwood, 1993; Greenwood and Wing, 1995; Walther et al., 2007; Eiserhardt et al., 2011; Archibald et al., 2014).

Fossil palm leaves are well known from Paleocene sites in the U.S.A. (Newberry, 1898; Hollick, 1936; Brown, 1962; DeVore and Pigg, 2010; Manchester, 2014), including: Colorado, Utah and Wyoming (e.g., Lesquereux, 1883; Newberry, 1898; Knowlton, 1930); Washington, from the Bellingham Bay Member of the Chuckanut Fm. (Newberry, 1863, 1898; Mustoe and Gannaway, 1995; Mustoe et al., 2007; Breedlovestrout et al., 2013), and even Alaska to about 61 N (Hollick, 1936; Wolfe, 1977; Sunderlin et al., 2011, 2014)(Figs. 1, 2). No Paleocene palm megafossils have been formally described from Canada (DeVore and Pigg, 2010); however, Aulenback (2009) figured a palm leaf from the Genesee early Paleocene site, noting that it was 'like' the extant species Serenoa repens (Bartram) 
J.K.Small. East of the Rocky Mountains, Brown (1962) reported that Paleocene palms were unknown north of the Yellowstone River in Montana (Fig. 1). Brown (1962) described a small-leaf palmate species, Palmacites dorfi (Brown) Read and Hickey from this area (Fig. 2C). Paleocene palms are also known from coastal northeast Siberia and the Kamchatka Peninsula (Akhmetiev, 2015), and China (Zhou et al., 2013). Paleoclimate estimates for the floras from the Upper Paleocene Bellingham Bay Member of the Chuckanut Formation are subtropical (mean annual temperatures (MAT) 16.5-22 ${ }^{\circ} \mathrm{C}$; Breedlovestrout et al., 2013), whereas the Alaskan Paleocene floras with Sabalites palms are reconstructed as temperate, with mean annual temperature (MAT) $11-15^{\circ} \mathrm{C}$, and cool but mostly frost free winters with cold month mean temperature (CMMT) $2.7-5.5^{\circ} \mathrm{C}$ (Sunderlin et al., 2011, 2014). The Alaskan Paleocene palms therefore appear to have occurred close to the modern temperature limits of most palms of MAT $>10{ }^{\circ} \mathrm{C}$ and $\mathrm{CMMT}>5{ }^{\circ} \mathrm{C}$ (Larcher and Winter, 1981; Greenwood and Wing, 1995).

In Canada, Paleocene leaf floras are known from the Scollard and Ravenscrag formations (e.g., Genesee in Alberta, and Ravenscrag in Saskatchewan: Chandrasekharam, 1974; McIver and Basinger, 1993), and the Paskapoo Formation (e.g., Gao Mine, Joffre Bridge and Munce's Hill, all in Alberta: Hoffman and Stockey, 1999; Stockey et al., 2013, 2014)(Fig. 1B). Paleocene leaf floras are also known from the N.W.T., Nunavut, and Yukon (Greenwood et al., 2010; Vavrek et al., 2012). However, with the exception of Aulenback's (2009) anecdotal report from Genesee, palm megafossils were not recorded from any of these Paleocene megafloras. The apparent absence of palms from Paleocene floras from east of the Rockies in Canada may be due to winters with freezing conditions throughout this area. 
In this report a new species of Paleocene palm leaf from the Genesee megaflora of the Scollard Formation of Alberta (Chandrasekharam, 1974; Stockey et al., 2014), is described and illustrated. The fossil palm leaves presented here are all fan palms (Sabalites, subfamily Coryphoideae), but lack sufficient diagnostic features to be assigned to a tribe or genus within the Coryphoideae. These new records of Sabalites (sensu Read and Hickey, 1972) from the Paleocene Genesee locality represent the northernmost records of Paleocene palm fossils in North America outside of Alaska. In order to provide a paleoclimate context, leaf physiognomy of the associated dicot leaf flora is used to derive estimates of climate from leaf morphotypes defined by Chandrasekharam (1974), supplemented with material from the University of Alberta, University of Saskatchewan, Royal Alberta Museum (RAM) and Royal Tyrrell Museum of Palaeontology (RTMP) Genesee collections.

\section{Materials and Methods}

\subsection{Genesee fossil locality}

The Genesee megaflora occurs in outcrop of Paleocene sediments on the south bank of the North Saskatchewan River in central Alberta, Canada, $70 \mathrm{~km}$ southwest of Edmonton $\left(53^{\circ} 21^{\prime} \mathrm{N}, 114^{\circ} 24^{\prime} \mathrm{W}\right)$, and is within the Genesee Natural Area protected site (Fig. 1) (Alberta Government, 2016). Chandrasekharam (1974) noted that the fossiliferous sediments at the Genesee fossil locality were stratigraphically higher than the Ardley Coal and assigned the Genesee flora sediments to the Scollard Member of the Paskapoo Formation, a unit now recognized as the Lower Paleocene upper member of the Scollard Formation of the Edmonton Group (Pollock et al., 2000). The Genesee open pit coal mine to the east of the Genesee Natural Area (Fig. 1C) intersects coals and shale from the Ardley Coal Zone of the upper member of the Scollard Formation (Pollock et al., 2000). However, both Rothwell and 
Stockey (1989) and Pigg and DeVore (2010) listed the Genesee flora as from Paskapoo Formation, and noted that it is associated with a Tiffanian mammal fauna (i.e., Late Paleocene). No mammal fossils are known from Genesee. Further, the Genesee fossil locality is within the mapped outcrop of the upper member of the Scollard Formation on the current geological map of Alberta (Prior et al., 2013). More recently, Stockey et al. (2014) listed the Genesee flora as being from the Lower Paleocene upper Scollard Formation, pollen zone P1, which is correlative with the Wodehouseia fimbriata Zone (Demchuk, 1990; Lerbekmo and Sweet, 2008), thus placing the Genesee flora stratigraphically as Early Paleocene, an age assignment we follow here.

Ferns, conifer shoots, and angiosperm leaves are common in a grey shale that crops out at several levels along the exposed section, which includes thin coal layers $(15-60 \mathrm{~cm})$, a conchoidally fractured brownish mudstone, a $\sim 28 \mathrm{~cm}$ thick brownish blocky shale, and thin bentonitic clay layers (Chandrasekharam, 1974). The Genesee megaflora is of low diversity, with about 19 species including broadleaf dicot leaf fossils (Cercidiphyllum, Platanus, Vitis and others), together with ferns, Metasequoia and rare Pinaceae, and is interpreted as a temperate polar broadleaf deciduous forest (Chandrasekharam, 1974; Rothwell and Stockey, 1989; Pigg and DeVore, 2010). Chandrasekharam (1974) interpreted the plant assemblage as indicating dry frost-free winters and wet summers under a warm, humid, temperate climate comparable to present day east-central China. Additional dicot leaf morphotypes to those described by Chandrasekharam (1974) were recognized while surveying the University of Alberta, University of Saskatchewan, Royal Alberta Museum (RAM) and Royal Tyrrell Museum of Palaeontology (RTMP) collections. Several specimens of small ( $<15 \mathrm{~cm}$ across) fan-palm leaves collected at the Genesee locality in 1995 by D. Braman (RTMP) were 
present in the RTMP collection (Aulenback, 2009). These very small palm leaves occur on the surfaces of thin mud-drapes within a coarser sedimentary matrix than is typical for Genesee plant fossils, and were collected a few metres upslope from the classic Genesee fossil plant beds (D. Braman, pers. commun., Feb. 2016), and are the subject of this report.

Palm fossils from the RTMP were photographed using low angle lighting (to highlight venation) using a Nikon D3200 DSLR 24-megapixel digital camera with a Nikon 55-200 mm DX VR lens. Images were slightly modified to remove lens geometric aberration, and to optimize contrast and brightness using the image-editing feature of the camera software. Detail images showing leaf venation were photographed using an Olympus MVX10 Macro Zoom microscope using the cellSens ${ }^{\mathrm{TM}}$ software (Olympus Corporation, 2011). Line drawings were prepared from the images using Adobe Photoshop CS6 ver. 13.0 x32 (Adobe Systems Inc., 2013) to highlight important features of the secondary venation. All specimens are curated in the Royal Tyrrell Museum of Palaeontology fossil plant collections (TMP numbers). An image of the holotype of Palmacites dorfi (Brown, 1962; Read and Hickey, 1972) from the Smithsonian Institution was analyzed for comparison to the Genesee palm.

\subsection{Modern palm comparative material}

Extant palm classification and nomenclature herein follows Baker et al. (2009), Baker and Couvreur (2013), and Baker and Dransfield (2016). Identification of palm leaf material was based in part on the key and definitions of palm organ fossil genera in Read and Hickey (1972) using leaf macroscopic features, with supplemental information about extant palms from Daghlian (1978), Zona (1990, 2000), and Horn et al. (2009). Additional measurements of palm leaf features (e.g., segment width and length, petiole width; Table 1) were obtained from herbarium specimens in the Atlas of Alabama and Atlas of Florida online herbarium 
databases (Keener et al., 2016; Wunderlin et al., 2016). Images of herbarium sheet specimens were downloaded and features of interest were measured using the digital measurement tool in the IC Measure ver. 1.2.0.233 software (The Imaging Source, 2015) that was calibrated using the scale provided in the herbarium sheet images. The largest and smallest specimens available as images were measured. Leaf segment width was measured at the widest point along each leaf segment, and petiole width was measured just below the attachment of the first leaf segment. Segment attachment (i.e., connate or not) was recorded as either segments separated for more than $50 \%$ of their length where typically the segments were widely spaced for much of the blade (e.g., Serenoa repens), or less than 50\% where the blade showed only free segments along its margin (e.g., Sabal etonia Swingle ex Nash).

\subsection{Paleoclimate analysis}

Limited paleoclimate data is available for the Paleocene of Alberta (Foreman et al., 2013). To provide a paleoclimatic context for the presence of palms in the Paleocene of Alberta, we undertook a preliminary analysis of the leaf physiognomy of the Genesee dicot leaf flora. As the original collection (Chandrasekaharam, 1974) had a very low number of dicot species $(n=11)$, we added to this original collection leaf architectural data from unique dicot leaf morphotypes found in the RTMP, RAM, University of Alberta, and University of Saskatchewan paleobotanical collections. The fossil leaves were sorted into 28 morphotypes using the templates and character definitions from the Manual of Leaf Architecture (MLA; Ellis et al., 2009). The MLA leaf size categories were used for leaf area analysis to provide an estimate of mean annual precipitation, as leaf size positively correlates with precipitation (Wilf et al., 1998). The same leaf morphotypes were also scored for CLAMP, which mathematically ordinates the linkages between leaf characters and climate, to derive 
estimates of annual and seasonal temperature, and of seasonal precipitation (Wolfe, 1995; Yang et al., 2015). The CLAMP method includes several alternative modern calibration data sets, and based on an initial exploration of the Genesee leaf physiognomic data using the PhysGlobal 378 data set, we applied the Physg3brcAZ_GRIDMet3brAZ calibration which employs gridded modern meteorological data (Yang et al., 2015). Leaf physiognomic data for the Genesee dicot leaf morphotypes are provided in Appendix S1, which include the scoring data for CLAMP, as well as the calibration equations used for leaf area analysis.

\section{Results}

\subsection{Systematics}

Family-Arecaceae Schultz Sch. (1832), nom. cons. et nom. alt.

Subfamily_Coryphoideae Burnett (1835)

Genus - Sabalites G. Saporta emend. Read et Hickey (1972).

Species—Sabalites geneseensis D.R. Greenw. \& C.K. West sp. nov.

Holotype-TMP 95.80.04 A and 95.80.04 B (leaf; Fig. 3 \& Fig. 4A, part and counterpart), collected by D. Braman, 1995.

Referred specimens - TMP 95.80.01, TMP 95.80.02, TMP 95.80.03 (Fig. 4), and TMP 95.80.48, TMP 95.80.49.

Repository-Palaeobotanical collection, Royal Tyrrell Museum of Palaeontology (TMP), Drumheller, Alberta, Canada.

Locality-53 $23^{\prime} \mathrm{N}, 114^{\circ} 24^{\prime} \mathrm{W}$, Genesee fossil locality, south bank of the North Saskatchewan River, central Alberta, Canada (Chandrasekharam, 1974; Rothwell and Stockey, 1989). 
Age and stratigraphy —Early Paleocene, upper member of the Scollard Formation.

Etymology - The specific epithet geneseensis is proposed, in reference to the locality where the fossil species was collected.

Diagnosis - Costapalmate palm leaves with a narrow elongate costa, the lamina middle segment no more than $15 \mathrm{~cm}$ long; transverse veins forming a zig-zag pattern; segments attached (connate) for $>50 \%$ of segment length, plication induplicate. Petiole unarmed.

Description - The leaf blade costapalmate with a narrow, straight-sided costa that extends at least $25 \%$ of the blades' length from a narrowly triangular base. The petiole on two specimens (Figs. 3A, 4B) was unarmed and c. $0.4 \mathrm{~cm}$ in width. No hastula was observed. Individual segments were measured for all referred specimens as more than $4.8 \mathrm{~cm}$ to about $12.7 \mathrm{~cm}$ in length (Table 1); however, as the available specimens were incomplete the segments are estimated to be potentially 10 to $15 \mathrm{~cm}$ in length. Segment apices were not preserved. Segments were connate (attached to adjoining segments) for most of their length $(>50 \%)$, and in the range of $0.3 \mathrm{~cm}$ to $\mathrm{c} .1 \mathrm{~cm}$ in width at their widest point. The available specimens were mostly incomplete, with the number of countable segments in the range 14 to 22 . The plication of the specimens was easily discernible and induplicate (v-shaped). Secondary veins were discernible on the type specimen (TMP 95.80.04) showing the presence of 5-8 secondary veins parallel to the segment mid-vein, with oblique ladder-like zig-zag pattern transverse veins that link both minor and major veins (Fig. 3C). This venation feature was observed on the counter-part (TMP 95.80.04 B, Fig. 4A), and on other partial specimens (e.g., 95.80.03 and 95.80.02 B, Fig. 4C-E), but poorly so on TMP 95.80.01 (Fig. 4B). No cuticle was found preserved on the Genesee palm material. 
Remarks - Palmate leaves are seen in several monocot families, with members of the extant Cyclanthaceae and Carludovica palmata Ruiz \& Pav. in particular recognized as having palm-like leaves (Wilder, 1972; Gunawardena and Dengler, 2006). The form of the fossil leaf however, is indicative of a costapalmate fan palm (Arecaceae, aff. subf. Coryphoideae), and not that of Cyclanthus, Carludovica palmata or other members of the Cyclanthaceae. Cyclanths can be differentiated from palmate palm leaves (fan palms) in key ways seen on the fossil: 1) in cyclanths, the veins extend to the end of the leaf, whereas in palm leaves, the veins end at the margins; 2) cyclanths always have more than one midrib or costa per leaf (bicostate in Cyclanthus, tricostate in Carludovica palmata), whereas palms always have a single midrib (Wilder, 1976), i.e. the single costa seen in Sabalites geneseensis.

The features useful for differentiating fan palm leaves on gross architecture alone include: leaf form (palmate or costapalmate); the size, degree of separation and the number of segments; the nature of leaf plication; segment apex shape; the venation of the segments; the shape of the costa; and the presence or absence of petiole armature (Daghlian, 1978; Dransfield et al., 1990, 2008)(Table 1). The specimens from Genesee lack sufficient diagnostic characters (such as epidermal features) to assign them to a Tribe or Genus in the Coryphoideae, and so are recognized as a species of Sabalites according to the criteria of Read and Hickey (1972). The leaves of Sabalites geneseensis are remarkably small at $<15$ $\mathrm{cm}$ across, with some specimens c. $5 \mathrm{~cm}$ across (Fig. 3C). The small size of these leaves alone differentiates them from any previously described Paleocene costapalmate palm species, which are otherwise difficult to differentiate based on leaf form alone. The lack of spines or other armature on the petiole distinguishes Sabalites geneseensis and also extant Sabal from other living genera of costapalmate palms (Daghlian, 1978; Dransfield et al., 2008). 
The presence of oblique transverse veins (cross veins of some authors) forming a zigzag pattern is distinctive in the holotype of S. geneseensis. Gomez-Navarro et al. (2009) similarly noted a distinctive sinuous pattern to the transverse veins present on their Paleocene costapalmate or palmate Arecaceae sp. 2; however, the systematic value of this feature is unclear. Dransfield et al. (2008) noted that in Sabal transverse veins may be obscure or conspicuous. Horn et al. (2009) found considerable homoplasy in their survey of palm leaf architecture and anatomy, but noted that most costapalmate and palmate coryphoid palms have orthogonal transverse veins, including Accoelorraphe wrightii, Brahea berlandieri, Serenoa repens (all Trachycarpeae), and Sabal minor. Zig-zag pattern oblique transverse veins are found in Chamaerops humilis, Rhapidophyllum hystrix, Rhapis excelsa, and Trachycarpus fortunei (all Trachycarpeae), as well as in some Cryosophileae, but this trait is also found in non-coryphoid palms (Horn et al., 2009). A hastula was not observed on Sabalites geneseensis, but this may not be meaningful as when present in living palms, the hastula may be on one surface only (cf. both adaxial and abaxial in Sabal) and so may be present on the unobserved surface in a fossil (Read and Hickey, 1972; Daghlian, 1978; Dransfield et al., 1990). However, the holotype includes both surfaces.

Modern palms show a very large range of leaf size, from less than $0.5 \mathrm{~m}$ long to in excess of $25 \mathrm{~m}$ (Horn et al., 2009). In comparison to members of the Trachycarpeae and Sabal from the southern U.S.A., Sabalites geneseensis is smaller than any of the living species surveyed (Table 1), only approaching in leaf size the procumbent species Serenoa repens, or that of very young plants. Gödel et al. (2015), however, recorded a mean leaf size of $11 \pm 4 \mathrm{~cm}$ for the Calamoid South American palm Mauritiella, which has a palmate leaf. In overall leaf size measured as middle segment length, Serenoa repens is slightly larger than 
Sabalites geneseensis ( $>4.8-12.7 \mathrm{~cm}$ vs. $17-35 \mathrm{~cm})$, but the extant species is comparable in size to the fossil species for segment width $(0.3-1 \mathrm{~cm}$ vs. $0.8-2.4 \mathrm{~cm})$, and petiole width (c. 0.4 vs. $0.3-0.6 \mathrm{~cm})($ Table 1). Segment size data was not available for Mauritiella. As the fossils were all incomplete, in life Sabalites geneseensis may have borne leaves of comparable size to smaller individuals of Serenoa repens. Sabalites geneseensis had a comparable number of segments (14-22), as both Acoelorraphe wrightii (17-25) and Serenoa repens (10-24), and much fewer segments than species of Sabal (15-65 to 35-70). With the exception of Rhapidophyllum hystrix, all of the surveyed species had an induplicate plication, in common with Sabalites geneseensis (Table 1). No spines, teeth or hooks were observed on the fossil petioles (Figs. 3, 4), as seen also in Sabal and R. hystrix; however, the petioles of Acoelorraphe wrightii, Brahea aculeata, and Serenoa repens have armed petioles (Table 1).

Knowlton $(1919,1930)$ and Brown (1962) described several palmate and costapalmate palm species from Paleocene to Eocene sediments, with some species occurring in both Epochs. Knowlton $(1919,1930)$ considered Sabalites campbelli (Newberry) Lesquereux, S. grandifolia (Newberry) Read and Hickey, Sabal inquirenda Knowlton, and $S$. ungeri (Lesquereux) E. Dorf, to be in part Sabalites grayanus Lesquereux. Brown (1962) synonymised many Paleocene to Eocene palm species, including Sabal campbelli, $S$. grandifolia, S. inquerenda, $S$. powelli (Newberry) Berry (in part), S. rugosa Knowlton, $S$. ungeri (Lesquereux) Knowlton, Sabalites eocenica (Lesquereux) Dorf, S. florisanti, Flabellaria alaskana, F. eocenica, and F. florisanti (= S. florisanti) into his broadly defined Sabal grayana (syn. Sabalites grayanus; Read and Hickey, 1972). Mustoe and Gannaway (2007) however, considered Sabalites grayanus a catch-all species, rejecting inclusion of $S$. campbelli material from the Chuckanut Formation, and noting that Brown included 
Paleocene material as well as the type material from the Middle Eocene of Mississippi. Read and Hickey (1972) accepted four species of Sabalites that Brown (1962) included within his concept of Sabal grayana: Sabalites grandifolia (Yellowstone volcanics, Eocene, MT), S. powellii (Green R. Fm., Eocene, WY), S. rugosa (Knowlton) Read and Hickey, and S. ungeri (latter 2 spp., Raton Fm., Paleocene, NM). Brown (1962) emphasized the size and shape of the costa (acumen in his usage) for separating fossil species of Sabal, whereas Knowlton (1930) referenced the number and size of leaf segments ('rays' of his work) and their venation.

Sabalites campbelli, S. grayanus material and related Paleocene to Eocene fan palm species from Colorado, Montana, New Mexico, Washington and Wyoming - however systematically treated - are typically quite large, exceeding $1 \mathrm{~m}$ in width (Brown, 1962). Additionally, all of these Sabal or Sabalites species have a robust costa (often referred to as an acumen) that is straight-sided or concave, and extending prominently into the blade, so unquestionably costapalmate (Kvaček and Herman, 2004). Sabalites grayanus has a costa that is concave (Daghlian, 1978), whereas S. geneseensis is a very small leaf with a straightsided costa extending from a narrowly triangular base. Further comparisons are therefore restricted to Paleocene-Eocene coryphoid leaves of a similar character to $S$. geneseensis. Kvaček and Herman (2004) provide a detailed account of Sabalites and fossil Sabal synonymy.

Berry (1924) described two fan palms with medium to small leaves; Sabalites vicksburgensis Berry (diameter up to $120 \mathrm{~cm}$ ) and Thrinax eocenica (syn. Palmacites eocenica (Berry) Daghlian) at 30 to $60+\mathrm{cm}$ (Fig. 2C). The size of the lamina of $S$. vicksburgensis is much greater than $S$. geneseensis, however both species have a slender 
petiole extending into a narrow straight costa, and connate segments with common transverse veins (Daghlian, 1978). Palmacites eocenica is palmate, not costapalmate, with spreadingfree not connate segments, but similar to $S$. geneseensis it has prominent secondary veins. Hollick (1936) described a small fan palm species from Kupreanof Island in Alaska (Fig. 1), Flabellaria alaskana, with leaves that were $45-50 \mathrm{~cm} \times 60-75 \mathrm{~cm}$ (c.f., Fig. 3D), as well as the much larger palmate species F. florisanti (syn. Palmacites florisanti (L. Lesquereux) Read and Hickey). Read and Hickey (1972) referred F. alaskana to Palmacites (P. alaskana (A. Hollick) Read and Hickey) as the material figured by Hollick (1936, pl. III) is palmate; however, the Paleocene fossil fan palm from Alaska shown in Figure 2D herein is costapalmate, and is consistent with Sabalites campbelli. The Paleocene species Sabalites geneseensis is considerably smaller than the Alaskan material of P. alaskana, S. cf. campbelli or P. florisanti.

Brown's (1962) species Palmacites dorfi (Brown) Read and Hickey from the Lower Paleocene Fort Union Formation in Montana is a palmate leaf with small blades described by Brown as $\sim 30 \mathrm{~cm}$ in diameter; however, the incomplete middle segment is $12.1 \mathrm{~cm}$ long when measured from a new image of Brown's specimen (Fig. 2C) using IC measure (The Imaging Source, 2015). Apart from the apparent difference of being palmate and not costapalmate, $P$. dorfi differs from $S$. geneseensis by having the outer-most segments reflexed below the plane of the base of the costa, forming an acute angle $\left(\sim 9^{\circ}\right)$ with the petiole versus the outermost segments in $S$. geneseensis all pointing upward from the plane of the base of the costa (Figs. 3, 4). Both of these Paleocene species are small (middle segment $<15 \mathrm{~cm}$ ), have connate segments (at least in the area preserved in $P$. dorfi) and unarmed petioles. 
Brown (1962) did not describe the segment venation of $P$. dorfi as this character was not preserved (e.g., Fig. 2C).

Daghlian (1978) examined in detail Early to Middle Eocene fan palms from southeastern USA, considering both leaf architectural as well as cuticular features. In that study Daghlian (1978) extended the scheme of Read and Hickey (1972) to include new genera of fossil palms, but also recognized some fossil leaf material as the extant genus Sabal (e.g., Sabal dortchii Daghlian) and rejected a record of Thrinax (Palmacites eocenica (Berry) Daghlian) on the basis of the form of the stomatal complex. Daghlian's (1978) genera have not been widely adopted (Zhou et al., 2013); however, he re-examined Sabalites grayanus, a species that is recorded from Paleocene sediments, as well as other fossil palm species. In Daghlian's (1978) amended diagnosis of S. grayanus he defined this species solely from Eocene material in keeping with the original designation of the type material. Further, Daghlian (1978) emphasized epidermal and stomatal characteristics from leaf cuticle in his amended diagnosis for S. grayanus and also for his diagnoses of several other fossil palms; however, cuticle was not present on the Genesee palms.

Daghlian (1978) did not record transverse veins for S. grayanus, Sabal dortchii, or the palmate species Palmacites eocenica, but noted they were frequent in his costapalmate species Costapalma philipii Daghlian. The Eocene species C. philipii has larger lamina than Sabalites geneseensis, at $>23 \mathrm{~cm}$ for the largest incomplete specimen (estimated $50-60 \mathrm{~cm}$ intact), with the outer-most segments reflexed down below the insertion of the petiole vs. upward in S. geneseensis. However, Daghlian (1978) also shows specimens of C. philipii with upward pointing outer-most segments (pl. 9, figs. 34, 35), and he noted that leaf segment arrangement and size varies with plant age in living Sabal mexicana Martinus; leaves of 
young plants have upward pointing outer segments (see pls 1 and 2 in Daghlian 1978).

Daghlian (1978) recorded 2-5 secondary veins linked by 'slightly oblique' transverse veins for C. philipii, but did not provide additional information as to their course. The palmate Eocene species Palustrapalma agathae Daghlian shows the same upward pointing connate segments as the costapalmate $S$. geneseensis. Daghlian (1978) did not report transverse veins for $P$. agathae, and at $>36 \mathrm{~cm}$ for the largest incomplete specimen this species was larger than S. geneseensis.

Kvaček and Herman (2004) reported oblique transverse veins in the Late Cretaceous species Sabalites longirachis (Unger) J. Kvaček et Herman; however, their line drawing shows rare orthogonal transverse veins linking smaller veins, not the oblique zig-zag pattern linking minor and major secondary veins seen in S. geneseensis. Transverse veins (cross veins of some authors) are rarely reported for fossil fan palm leaves due to poor preservation of this feature (e.g., Hollick, 1936; Brown, 1962; Daghlian, 1978; Kvaček and Herman, 2004; Gomez-Navarro et al., 2009; Srivastava et al., 2014; Wang et al., 2015).

\subsection{Paleoclimate}

Chandrasekharam (1974) described 11 dicot leaf morphotypes from the Genesee flora. Combined with additional leaf morphotypes recognized from the RTMP, RAM and university collections, 28 leaf morphotypes were scored for leaf architectural features for climate analysis (Appendix S1). Based on these leaf morphotypes, MAT for Genesee was

estimated at $11{ }^{\circ} \mathrm{C}\left( \pm 2.1^{\circ} \mathrm{C}\right)$ using CLAMP (Yang et al. 2015)(Table 2). Winter temperatures estimated from CLAMP were mild (CMMT $\left.2.4{ }^{\circ} \mathrm{C} \pm 3.4{ }^{\circ} \mathrm{C}\right)$ and indicate frost was possible in winter. Using the same leaf morphotypes, MAP was estimated as $>147 \mathrm{~cm} / \mathrm{year}(210+91$, $-63 \mathrm{~cm} / \mathrm{yr})$ using the leaf area analysis (LAA) 'indirect approach' and $>130 \mathrm{~cm} / \mathrm{year}(186$ 
$+80,-56 \mathrm{~cm} / \mathrm{yr}$ ) using the 'direct measurement approach' (Wilf et al. 1998). Growing season precipitation was estimated from CLAMP at $47 \mathrm{~cm}$ (for a 6.7 month growing season) with high uncertainty for this estimate, indicating a drier climate than reconstructed from LAA, but still humid (e.g., RH 84\%; Table 2).

\section{Discussion}

The costaplamate specimens from Genesee lack sufficient diagnostic characters to assign them to a Tribe or Genus in the Coryphoideae, and so are recognized as a species of Sabalites (Read and Hickey, 1972). Some features of S. geneseensis are consistent with the extant genus Sabal (e.g., the non-armed petiole on a costapalmate leaf, mostly connate segments) but other features are shared with members of the Trachycarpeae or other coryphoid palms (Table 1). The other palm leaf material from the Genesee locality in the RTMP collections consisted of lamina pieces showing several plicate and connate leaf segments aligned parallel to each other, with a strong mid-vein and secondary veins parallel to the mid-vein. These referred specimens lack a costa, petiole, rachis or other evidence allowing determination of the original leaf form (i.e., palmate, costapalmate or pinnate; Fig. 3C-E). Under the system of Read and Hickey (1972) these fossils are recognized as palms but these leaf fragments should be placed in Amesoneuron H.R. Göppert, 1852 emend. Read and Hickey, as they are isolated fragmentary segments lacking marginal teeth or spines. However, because the non-petiolate specimens were collected from the same strata within a small horizontal exposure, and are morphologically identical in all other respects with the petiolate material, these specimens are not here treated as a separate fossil palm species, but instead are referred to Sabalites geneseensis. 
Costapalmate and palmate leaves are typical of the Subfamily Coryphoideae, as typified by Sabal (Tribe Sabaleae), Tribe Cryosophileae (e.g., Coccothrinax), and the Tribe Trachycarpeae, but this leaf form is also found in three calamoid palm genera in the Lepidocaryeae (Horn et al., 2009). Lepidocaryum Mart., Mauritia L.f., and Mauritiella Burret (Lepidocaryeae: Mauritiinae), however are palmate and not costapalmate (Dransfield et al., 2008). Amongst the Coryphoideae found naturally in the U.S.A., Acoelorraphe, Coccothrinax, Serenoa and Thrinax are palmate (i.e., lack a costa), while a range of other coryphoid genera such as Brahea, Rhapidophyllum, Washingtonia, and Sabal are costapalmate (Daghlian, 1978; Zona, 2000; Table 1). Brahea aculeata (Brandegee) Moore from Mexico, however, is palmate. Horn et al. (2009) noted that palmate leaves (in their broader sense, i.e., including both palmate and costapalmate leaves) show a range of anatomies, and that leaf form across palm clades shows a number of reversals reflecting adaptations to arid and cold environments. The costapalmate leaf type is therefore not especially significant in terms of biogeography, although this leaf form is exclusively found in the Coryphoideae. Sabalites was assumed by some authors to represent Sabal (e.g., Zona 1990, pp. 615-616), but for Eocene and older material, Sabalites fossils should be viewed solely as evidence of costapalmate members of the Coryphoideae (e.g., Dransfield et al., 2008; DeVore and Pigg, 2010; Couvreur et al., 2011; Iles et al., 2015).

\subsection{Palm paleobiology and paleobiogeography}

Both the Sabaleae and Trachycarpeae tribes contain most of the coldest tolerant extant palms; e.g., Sabal, Trachycarpus, and Washingtonia (Eiserhardt et al., 2011; Archibald et al., 2014; Gushulak et al., 2016). Palmate or costapalmate coryphoid palms are the dominant palms in North American Paleocene and Eocene megafloras; pinnate forms are rare in these 
megafloras, but include the coryphoid palm Phoenix (Brown, 1962; DeVore and Pigg, 2010; Manchester, 2014; Allen, 2015). Previous analyses have demonstrated that climate was the primary determinant of the distribution of palm species within the landscape, and that the species richness of palms is strongly controlled by climate, principally temperature and precipitation (Bjorholm et al., 2006; Eiserhardt et al., 2011). The global limit of palms essentially coincides with the tropics and subtropics, with only a small number of species reaching warm temperate regions (Larcher and Winter, 1981; Greenwood and Wing, 1995; Bjorholm et al., 2006; Eiserhardt et al., 2011). The temperature niche conservatism of palms is due to their soft and water-rich tissues, typically a single growing tip, an inability (with few exceptions) to enter dormancy, and their general lack of frost tolerance mechanisms (Larcher and Winter, 1981; Eiserhardt et al., 2011).

The phylogenetic analyses of Couvreur et al. (2011), Bacon et al. (2012), and Baker and Couvreur (2013) treated Sabalites as a generalized fan-palm type (Coryphoideae, but not evidence of Sabal or Tribe Sabaleae), recognizing its taxonomic uncertainty with a record that extends into the Cretaceous (Dransfield et al., 2008; Manchester et al., 2010; Couvreur et al., 2011; Iles et al., 2015). Manchester et al. (2010), however, recognized Sabal (i.e., Tribe Sabaleae) from seeds in the Upper Cretaceous Aguja Formation flora, and acknowledged the taxonomic uncertainty of associated Sabalites leaves. Palm phylogenetic analyses have demonstrated successive Cenozoic radiations, with Subfamily Coryphoideae, and the Tribe Trachycarpeae in particular, showing key radiations in the Paleogene (mostly post midEocene) and early Neogene involving adaptation to non-tropical rainforest and temperate habitats as part of their boreotropical dispersal through the Americas (Couvreur et al., 2011; Bacon et al., 2012; Baker and Couvreur, 2013). Pole and MacPhail (1996) found Nypa fruits 
and leaves in association with a temperate-character flora in the Early Eocene of Tasmania (palaeolat. $65^{\circ} \mathrm{S}$ ), but invoked warm monsoonal but not megathermal conditions in coastal areas to explain the presence of the tropical mangrove palm. The paleoclimate of the Upper Paleocene Bellingham Bay Member of the Chuckanut Formation is reconstructed as subtropical and wet, consistent with the presence of palms (Breedlovestrout et al., 2013; Foreman et al., 2013). The Sabalites from Alberta, however, are associated with a microthermal or temperate flora with a low diversity of plants (Chandrasekharam, 1974; DeVore and Pigg, 2010), an environment inconsistent with the presence of palms, particularly so-early in the Cenozoic.

Sabalites campbelli leaves from the Bellingham Bay Member of the Chuckanut Formation are $\sim 2 \mathrm{~m}$ in diameter (Mustoe and Gannaway, 1995)(Fig. 2A), typical of many subtropical species (e.g., Table 1). Late Paleocene palms from Alaska (e.g., Sunderlin et al., 2011, 2014), however are small, less than $1 \mathrm{~m}$ in diameter (Fig. 2B), consistent with small statured plants such as the extant Sabal minor or Serenoa repens. Similarly, Palmacites dorfi from the Early Paleocene of Montana (Brown, 1962) is a small leaf (Fig. 2C). The Early Paleocene Sabalites geneseensis leaves from Alberta are smaller still, with leaves comparable in size to the procumbent low statured extant species, Serenoa repens (Table 1). Aulenback (2009) likened the Genesee material to Serenoa repens, but as discussed in this report, the fossils lack features that would allow identification as Serenoa or any other member of the Trachycarpeae, or as Sabal. An early Maastrichtian specimen of a procumbent palm trunk was reported by Aulenback (2009) from the upper Horseshoe Canyon Formation of Alberta. The Early Eocene species Uhlia allenbyensis from British Columbia shared some anatomical features with Serenoa, Rhapidophyllum and Brahea, and had a procumbent trunk (Erwin and 
Stockey, 1994). However, no palm stems or trunks have been found in the Scollard Formation, so it is unknown whether the Genesee fossil leaves were from an erect trunked species, or a palm that produced leaves from an underground stem, or from a procumbent stem. Nonetheless, owing to the very small size of the leaf fossils we reconstruct Sabalites geneseensis as either a palmetto type palm with a small or non-existent trunk as seen in extant Sabal etonia and S. minor, or as procumbent stem as seen in extant Serenoa repens (Fig. 5).

\subsection{Paleoclimate}

Our climate estimates for Genesee (Table 2) are based on a preliminary dicot leaf physiognomic analysis of three separate collections from the Genesee locality, so must be used cautiously. However, the mean annual temperature $\left(11 \pm 2.1^{\circ} \mathrm{C}\right)$ and precipitation estimates (MAP > $130 \mathrm{~cm} / \mathrm{yr}$ ) are consistent with modelling and geochemical data for central Alberta in the Paleocene (MAT $\sim 10^{\circ} \mathrm{C}, \mathrm{MAP}>100 \mathrm{~cm} / \mathrm{yr}$; Foreman et al. 2013). Our data are equivocal for precipitation as the growing season precipitation was estimated using CLAMP at $47 \pm 32 \mathrm{~cm}$ (Table 2), implying a drier overall climate than the MAP estimate from leaf area analysis, but still a humid climate as predicted by Chandrasekharam (1974). The precipitation of the three driest months was estimated at $23 \mathrm{~cm}$ vs. $34 \mathrm{~cm}$ for the three wettest months with large uncertainties (Table 2), implying modest seasonality of precipitation. Sunderlin et al. $(2011,2013)$ applying the same leaf physiognomy-based methods for the Alaskan late Paleocene floras with palms as used here for Genesee, estimated MAT as 11-15 ${ }^{\circ} \mathrm{C}$, cold month mean temperature $2.7-5.5^{\circ} \mathrm{C}$, and MAP $\sim 120 \mathrm{~cm} /$ year. Most palms are restricted to climates where MAT $>10{ }^{\circ} \mathrm{C}$ and $\mathrm{CMMT}>5{ }^{\circ} \mathrm{C}$ (Larcher and Winter, 1981; Wing and Greenwood, 1993; Greenwood and Wing, 1995), although some temperate palm 
species can occur in areas where CMMT $\sim 2{ }^{\circ} \mathrm{C}$ (Walther et al., 2007; Gushulak et al., 2016), matching the CMMT value from CLAMP for Genesee (i.e., CMMT $2.4{ }^{\circ} \mathrm{C} \pm 3.4{ }^{\circ} \mathrm{C}$ ). Leaf size declines in palm species as they reach their climatic limits (Gödel et al., 2015), whether through cold or low rainfall, and the Alberta (Genesee) and Alaska Paleocene palms represented palm populations growing close to their climatic limits.

\section{Conclusions}

The North American Paleocene record is rich with palm fossils, ranging geographically from New Mexico to Alaska (Fig. 1), and includes palm leaves, wood, flowers, trunk moulds, seeds and pollen (e.g., Brown, 1962; Mustoe and Gannaway, 1995; Harley and Baker, 2001; Harley, 2006; Dransfield et al., 2008; DeVore and Pigg, 2010; Manchester, 2014). Records of Paleocene palms in North America extend as far as $61^{\circ} \mathrm{N}$ in coastal areas (Fig. 1), a distribution replicated in Siberia and Kamchatka (Akhmetiev, 2015). Hitherto, all of the North American Paleocene palm fossil material has been found outside of Canada, and east of the Rocky Mountains Paleocene palms did not extend further north than Montana. Sabalites geneseensis from the Paleocene Genesee megaflora near Edmonton, Alberta (Figs. 1, 3, 4), is the smallest known coryphoid palm with leaves 5-15 cm in length, and was part of a mixed conifer-dicot polar deciduous forest under a temperate moist climate (MAT $\sim 11^{\circ} \mathrm{C}, \mathrm{CMMT} \sim 3{ }^{\circ} \mathrm{C}, \mathrm{MAP}>130 \mathrm{~cm} / \mathrm{yr}$ ). This new record of Paleocene palms from Alberta shows that palms grew east of the Rockies in Canada, but that continental interior palms did not extend as far north as coastal Paleocene palms. The temperature estimates for Genesee - and therefore $S$. geneseensis - demonstrates adaptation by coryphoid palms to temperate climates before the Eocene-Miocene radiation of Trachycarpeae out of tropical rainforests into cooler and drier environments. 


\section{Acknowledgements}

DRG thanks the following for providing fossil palm images: George Mustoe for palm fossils from the Chuckanut Formation, Dave Sunderlin for palms from Alaska, and Scott Wing and Jonathan Wingerath for arranging the image of Palmacites dorfi from Montana from the Smithsonian. We particularly thank Dennis Braman, Jim Gardner, Graeme Housego and Brandon Strilisky of the Royal Tyrrell Museum of Palaeontology (RTMP) for assistance accessing the Genesee palm fossils and for providing photographs of the RTMP Genesee leaf collection. We also thank Jim Basinger for access to his Genesee collection at the University of Saskatchewan, Britta Jensen for specimens from the Royal Alberta Museum, and Georgia Hoffman for assistance on the Genesee locality and access to the University of Alberta collection. This work was supported by the Natural Sciences and Engineering Research Council of Canada [grant 2016-04337]; and the Canada Foundation for Innovation [project 31801]. Support for travel to the RTMP was provided by the Royal Tyrrell Museum Cooperating Society. CKW's contribution is supported by a Doctoral scholarship (PGS D) from NSERC. We thank two anonymous reviewers for their constructive comments.

\section{References}

Adobe Systems Incorporated, 2013. Adobe Photoshop CS6 User Guide. Web document: http://help.adobe.com/archive/en/photoshop/cs6/photoshop_reference.pdf [Accessed 22 May 2016].

Akhmetiev, M.A., 2015. High-latitude regions of Siberia and Northeast Russia in the Paleogene: Stratigraphy, flora, climate, coal accumulation. Stratigraphy and Geological Correlation 23(4), 421-435. 
Alberta Government, 2016. Genesee Natural Area. Alberta Parks. Website: http:// www.albertaparks.ca/genesee/ [Accessed 22 May 2016].

Allen, S.E., 2015. Fossil Palm Flowers from the Eocene of the Rocky Mountain Region with Affinities to Phoenix L. (Arecaceae: Coryphoideae). International Journal of Plant Sciences 176(6), 586-596.

Archibald, S.B., Morse, G., Greenwood, D.R., and Mathewes, R.W. 2014. Fossil palm beetles refine upland winter temperatures in the Early Eocene Climatic Optimum. Proceedings of the National Academy of Sciences, 111 (22): 8095-8100.

Aulenback, K. 2009. Identification Guide to the Fossil Plants of the Horseshoe Canyon Formation of Drumheller, Alberta. University of Calgary Press, Calgary. 396 pp.

Bacon, C.D., Baker, W.J., and Simmons, M.P., 2012. Miocene dispersal drives island radiations in the palm tribe Trachycarpeae (Arecaceae). Systematic Biology 61(3), $426-442$.

Baker, W.J., Savolainen, V., Asmussen-Lange, C.B., Chase, M.W., Dransfield, J., Forest, F., Harley, M.M., Uhl, N.W., and Wilkinson, M., 2009. Complete generic-level phylogenetic analyses of palms (Arecaceae) with comparisons of supertree and supermatrix approaches. Systematic Biology 58(2), 240-256.

Baker, W.J., and Couvreur, T.L.P., 2013. Global biogeography and diversification of palms sheds light on the evolution of tropical lineages. I. Historical biogeography. Journal of Biogeography 40, 274-285. 
Baker, W.J. and Dransfield, J., 2016. Beyond Genera Palmarum: progress and prospects in palm systematics. Botanical Journal of the Linnean Society 181, doi: 10.1111/boj. 12401

Berry, E.W., 1924. The middle and upper Eocene floras of southeastern North America. USGS Professional Paper 92. US Gov't. Print. Office.

Bjorholm, S., Svenning, J. C., Baker, W. J., Skov, F., and Balslev, H., 2006. Historical legacies in the geographical diversity patterns of New World palm (Arecaceae) subfamilies. Botanical Journal of the Linnean Society 151(1), 113-125.

Breedlovestrout, R.L., Evraets, B. J., and Parrish, J.T., 2013. New Paleogene climate analysis of western Washington using physiognomic characteristics of fossil leaves. Paleogeography, Palaeoclimatology, Palaeoecology 392, 22-40.

Brown, R.W. 1962. Paleocene flora of the Rocky Mountains and Great Plains. U.S. Geological Survey Professional Paper 375, 119 pp. +69 pl.

Chandrasekharam, A., 1974. Megafossil flora from the Genesee Locality, Alberta, Canada. Palaeontographica Abteilung B 147, 1-41.

Couvreur, T.L., Forest, F. and Baker, W.J., 2011. Origin and global diversification patterns of tropical rain forests: inferences from a complete genus-level phylogeny of palms. BMC Biology 9(1), 44. doi: 10.1186/1741-7007-9-44

Daghlian, C.P., 1978. Coryphoid palms from the Lower and Middle Eocene of Southeastern North America. Palaeontographica Abteilung B 166 ( 1-3), 44-82.

Demchuk, T.D., 1990. Palynostratigraphic zonation of Paleocene strata in the central and south-central Alberta Plains. Canadian Journal of Earth Sciences 27(10), 1263-1269. 
DeVore, M.L., and Pigg, K.B., 2010. Floristic composition and transitions of middle Eocene to late Eocene and Oligocene floras in North America. Bulletin of Geosciences 85, $111-134$

Dransfield, J., Ferguson, I.K., and Uhl, N.W., 1990. The coryphoid palms: patterns of variation and evolution. Annals of the Missouri Botanical Garden 77(4), 802-815.

Dransfield, J., Uhl, N.W., Asmussen, C.B., Baker, W.J., Harley, M.M. and Lewis, C.E., 2008. Genera palmarum. The Evolution and Classification of Palms. The Board of Trustees of Royal Botanic Gardens, Kew.

Eiserhardt, W.L., Svenning, J.C., Kissling, W.D., and Balslev, H., 2011. Geographical ecology of the palms (Arecaceae): determinants of diversity and distributions across spatial scales. Annals of Botany 108(8), 1391-1416.

Ellis, B., Daly, D.C., Hickey, L.J., Johnson, K.R., Mitchell, J.D., Wilf, P., and Wing, S.L. 2009. Manual of Leaf Architecture. Cornell University Press, Ithaca, N.Y.

Erwin, D.M., and Stockey, R.A. 1994. Permineralized monocotyledons from the middle Eocene Princton chert (Allenby Formation) of British Columbia: Arecaceae. Palaeontographica Abteilung B 234, 19-40.

Foreman, B.Z., Clementz, M.T. and Heller, P.L., 2013. Evaluation of paleoclimatic conditions east and west of the southern Canadian Cordillera in the mid-late Paleocene using bulk organic $\delta^{13} \mathrm{C}$ records. Palaeogeography, Palaeoclimatology, Palaeoecology 376, $103-113$.

Göldel, B., Kissling, W.D., and Svenning, J.-C., 2015. Geographical variation and environmental correlates of functional trait distributions in palms (Arecaceae) across 
the New World. Botanical Journal of the Linnean Society 179, 602-617. doi: 10.1111/ boj.12349.

Gomez-Navarro, C., Jaramillo, C., Herrera, F., Wing, S.L. and Callejas, R., 2009. Palms (Arecaceae) from a Paleocene rainforest of northern Colombia. American Journal of Botany 96(7), 1300-1312.

Greenwood, D.R., and Wing, S.L., 1995. Eocene continental climates and latitudinal temperature gradients. Geology 23(11), 1044-1048.

Greenwood, D.R., Basinger, J.F., and Smith, R.Y., 2010. How wet was the Arctic Eocene rain forest? Estimates of precipitation from Paleogene Arctic macrofloras. Geology 38(1), $15-18$.

Gunawardena, A.H., and Dengler, N.G., 2006. Alternative modes of leaf dissection in monocotyledons. Botanical Journal of the Linnean Society 150(1), 25--44.

Gushulak, C.A.C., West, C.K., and Greenwood, D.R. 2016. Paleoclimate and precipitation seasonality of the Early Eocene McAbee megaflora, Kamloops Group, British Columbia. Canadian Journal of Earth Sciences 53(6), 591-604. doi: 10.1139/ cjes-2015-0160

Harley, M.M., 2006. A summary of fossil records for Arecaceae. Botanical Journal of the Linnean Society 151, 39-67.

Harley, M.M., and Baker, W.J., 2001. Pollen aperture morphology in Arecaceae: application within phylogenetic analyses, and a summary of the fossil record of palm-like pollen. Grana 40, 45-77. 
Hoffman, G.L., and Stockey, R.A., 1999. Geological setting and paleobotany of the Joffre Bridge Roadcut fossil locality (Late Paleocene), Red Deer Valley, Alberta. Canadian Journal of Earth Sciences 36(12), 2073-2084. doi:10.1139/cjes-36-12-2073.

Hollick, C.A., 1936. The Tertiary floras of Alaska. U.S. Geological Survey Prof. Paper 182. US Gov't. Print. Office.

Horn, J.W., Fisher, J.B., Tomlinson, P.B., Lewis, C.E., and Laubengayer, K., 2009. Evolution of lamina anatomy in the palm family (Arecaceae). American Journal of Botany 96(8), 1462-1486. doi: 10.3732/ajb.0800396

Iles, W.J.D., Smith, S.Y., Gandolfo, M.A., and Graham, S.W., 2015. Monocot fossils suitable for molecular dating analyses. Botanical Journal of the Linnean Society 178, 346374. doi: 10.1111/boj.12233

Keener, B.R., Diamond, A.R., Davenport, L.J., Davison, P.G., Ginzbarg, S.L., Hansen, C.J., Major, C.S., Spaulding, D.D., Triplett, J.K., and Woods, M., 2016. Alabama Plant Atlas. University of West Alabama, Livingston, Alabama, USA. Website: http:// www.floraofalabama.org/ [accessed 20 March 2016].

Kissling, W.D., Eiserhardt, W.L., Baker, W.J., Borchsenius, F., Couvreur, T.L., Balslev, H., and Svenning, J.C., 2012a. Cenozoic imprints on the phylogenetic structure of palm species assemblages worldwide. Proceedings of the National Academy of Sciences 109(19), 7379-7384.

Kissling, W.D., Baker, W.J., Balslev, H., Barfod, A.S., Borchsenius, F., Dransfield, J., Govaerts, R., and Svenning, J.C., 2012b. Quaternary and pre-Quaternary historical 
legacies in the global distribution of a major tropical plant lineage. Global Ecology and Biogeography 21(9), 909-921.

Knowlton, F.H., 1919. A catalogue of Mesozoic and Cenozoic plants of North America (Vol. 696). US Government Printing Office.

Knowlton, F.H., 1930. The flora of the Denver and associated formations of Colorado. USGS Professional Paper 155. US Government Printing Office.

Kvaček, J. and Herman, A.B., 2004. Monocotyledons from the early Campanian (Cretaceous) of Grünbach, lower Austria. Review of Palaeobotany and Palynology 128(3), 323353.

Larcher, W., and Winter, A., 1981. Frost susceptibility of palms: Experimental data and their interpretation. Principes 25, 143-52.

Lerbekmo, J.F., and Sweet, A.R., 2008. Magnetobiostratigraphy of the continental Paleocene upper Coalspur and Paskapoo formations near Hinton, Alberta. Bulletin of Canadian Petroleum Geology 56(2), 118-146.

Lesquereux, L., 1883. Contributions to the fossil flora of the western territories. Part III. The Cretaceous and Tertiary floras. U.S. Geological Survey of the Territories, Report, Vol. 8,283 pp. +59 pl.

Manchester, S.R., 2014. Revisions to Roland Brown's North American Paleocene flora. Acta Musei Nationalis Pragae Series B - Historia Naturalis 70(3-4), 153-210.

Manchester, S.R., Lehman, T.M. and Wheeler, E.A., 2010. Fossil palms (Arecaceae, Coryphoideae) associated with juvenile herbivorous dinosaurs in the upper 
Cretaceous Aguja formation, Big Bend National Park, Texas. International Journal of Plant Sciences 171(6), 679-689.

McIver, E.E. and Basinger, J.F., 1993. Flora of the Ravenscrag Formation (Paleocene), southwestern Saskatchewan, Canada. Palaeontographica Canadiana 10, 1-167.

Mustoe, G.E., and Gannaway, W.L., 1995. Palm fossils from northwest Washington. Washington Geology 23 (2), 21-26.

Mustoe, G.E., Dillhoff, R.M., and Dillhoff, T.A., 2007. Geology and paleontology of the early Tertiary Chuckanut Formation. In: Stelling, P., and Tucker, D.S. (Eds.), Floods, Faults, and Fire: Geological Field Trips in Washington State and Southwest British Columbia: Geological Society of America Field Guide 9, pp. 121-135. doi: 10.1130/2007.fl d009(06).

Newberry, J.S., 1863. Species of plants collected by Dr. John Evans at Nanaimo (Vancouver Island) and at Bellingham Bay, Washington Territory. Boston Journal of Natural History 7, 506-524.

Newberry, J.S. 1898. The later extinct floras of North America. Monographs of the US Geological Survey vol. 35. US Government Printing Office. 295 pp.

Olympus Corporation, 2011. CellSens. Web site: http://www.olympus-lifescience.com/en/ software/cellsens/ [accessed 30 May 2016]

Pigg, K.B., and Devore, M.L., 2010. Floristic composition and variation in late Paleocene to early Eocene floras in North America. Bulletin of Geosciences 85(1), 135-154.

Pole, M.S. and Macphail, M.K., 1996. Eocene Nypa from Regatta Point, Tasmania. Review of Palaeobotany and Palynology 92(1), 55-67. 
Pollock, S.M., Goodarzi, F. and Riediger, C.L., 2000. Mineralogical and elemental variation of coal from Alberta, Canada: an example from the No. 2 seam, Genesee Mine. International Journal of Coal Geology 43(1), 259-286.

Prior, G.J., Hathway, B., Glombick, P.M., Pană, D.I., Banks, C.J., Hay, D.C., Schneider, C.L., Grobe, M., Elgr, R. and Weiss, J.A., 2013. Bedrock geology of Alberta. Alberta Energy Regulator, AER/AGS Map 600, scale 1:1 000000.

Read, R.W., and Hickey, L.J., 1972. A revised classification of fossil palm and palm-like leaves. Taxon 21, 129-137.

Rothwell, G.W. and Stockey, R.A., 1989. Fossil Ophioglossales in the Paleocene of western North America. American Journal of Botany 76(5), 637-644.

Srivastava, R., Srivastava, G. and Dilcher, D.L., 2014. Coryphoid palm leaf fossils from the Maastrichtian-Danian of Central India with remarks on phytogeography of the Coryphoideae (Arecaceae). PloS one 9(11), p.e111738.

Stockey, R.A., Hoffman, G.L. and Rothwell, G.W., 2013. Paleobotany and paleoecology of Gao Mine, a late Paleocene fossil locality near Red Deer, Alberta, Canada. Canadian Journal of Earth Sciences 50, 235-248. doi:10.1139/cjes-2012-0073

Stockey, R.A., Hoffman, G.L. and Vavrek, M.J., 2014. Paleobotany and paleoecology of the Munce's Hill fossil locality near Red Deer, Alberta, Canada. In: Stevens, W.D., Montiel, O.M., Raven, P.H. (Eds.), Paleobotany and Biogeography: A festschrift for Alan Graham in his 80th year. MSB 128. Missouri Botanical Garden Press, St. Louis, MO. pp. 367-388. 
Sunderlin, D., Loope, G., Parker, N.E., Williams, C.J., 2011. Paleoclimatic and paleoecological implications of a Paleocene-Eocene fossil leaf assemblage, Chickaloon Formation, Alaska. Palaios 26, 335-345.

Sunderlin, D., Trop, J.M., Idleman, B.D., Brannick, A., White, J.G. and Grande, L., 2014. Paleoenvironment and paleoecology of a late Paleocene high-latitude terrestrial succession, Arkose Ridge Formation at Box Canyon, southern Talkeetna Mountains, Alaska. Palaeogeography, Palaeoclimatology, Palaeoecology 401, 57-80.

The Imaging Source. 2015. IC Measure, manual on-screen image measurement and image acquisition. Website: http://www.theimagingsource.com/en_US/support/downloads/ details/icmeasure/ [accessed 20 March 2016]

Vavrek, M.J., Evans, D.C., Braman, D.R., Campione, N.E. and Zazula, G.D., 2012. A Paleogene flora from the upper Bonnet Plume formation of northeast Yukon Territory, Canada. Canadian Journal of Earth Sciences 49(3), 547-558.

Walther, G.R., Gritti, E.S., Berger, S., Hickler, T., Tang, Z., and Sykes, M.T., 2007. Palms tracking climate change. Global Ecology and Biogeography 16, 801-809. doi: 10.1111/j.1466-8238.2007.00328.x.

Wang, Q.J., Ma, F.J., Dong, J.L., Yang, Y., Jin, P.H. and Sun, B.N., 2015. Coryphoid palms from the Oligocene of China and their biogeographical implications. Comptes rendus Palevol. 14(4), 263-279.

Wilder, G.J., 1976. Structure and development of leaves in Carludovica palmata (Cyclanthaceae) with reference to other Cyclanthaceae and Palmae. American Journal of Botany 63, 1237-1256. 
Wilf, P., Wing, S.L., Greenwood, D.R. and Greenwood, C.L., 1998. Using fossil leaves as paleoprecipitation indicators. An Eocene example. Geology 26, 203-206.

Wing, S.L. and Greenwood, D.R., 1993. Fossils and fossil climates: the case for equable Eocene continental interiors. Philosophical Transactions of the Royal Society of London B 341, 243-252.

Wolfe, J.A., 1977. Paleogene floras from the Gulf of Alaska Region. U.S. Geological Survey Professional Paper 997.

Wolfe, J.A., 1995. Paleoclimatic estimates from Tertiary leaf assemblages. Ann. Rev. Earth Planet Sci. 23, 119-142.

Wunderlin, R.P., Hansen, B.F., Franck, A R. and Essig, F.B., 2016. Atlas of Florida Plants Institute for Systematic Botany, University of South Florida, Tampa, USA. Website: http://florida.plantatlas.usf.edu/ [accessed 20 March 2016]

Yang, J., Spicer, R.A., Spicer, T.E.V., Arens, N.C., Jacques, F.M.B., Su, T., Kennedy, E.M., Herman, A.B., Steart, D.C., Srivastava, G., Mehrotra, R.C., Valdes, P.J., Mehrotra, N.C., Zhou, Z.K. and Lai, J.S. 2015. Leaf Form-Climate Relationships on the Global Stage: An Ensemble of Characters. Global Ecology and Biogeography 24(10), 11131125.

Zona, S., 1990. A monograph of Sabal (Arecaceae: Coryphoideae). Aliso 12(4), 583-666.

Zona, S., 2000. Arecaceae, In: Flora of North America Editorial Committee (Eds), Flora of North America North of Mexico: Magnoliophyta: Alismatidae, Arecidae, Commelinidae (in part), and Zingiberidae. $19+$ vols. New York and Oxford. Vol. 22. 
Web document: http://www.efloras.org/florataxon.aspx?flora_id=1\&taxon_id=10061 [accessed 7 December 2015]

Zhou, W., Liu, X., Xu, Q., Huang, K. and Jin, J., 2013. New coryphoid fossil palm leaves (Arecaceae: Coryphoideae) from the Eocene Changchang Basin of Hainan Island, South China. Science China Earth Sciences 56(9): 1493-1501. 
Table 1. Leaf character states for selected species of subfamily Coryphoideae (Arecaceae) from North America contrasted to the fossil species (F). Data from Brown (1962), Daghlian (1978), Zona (1990, 2000), and measured herbarium and fossil specimens.

\begin{tabular}{|c|c|c|c|c|c|c|c|c|}
\hline species & $\begin{array}{c}\text { Le } \\
\text { af } \\
\text { for } \\
m\end{array}$ & $\begin{array}{l}\text { petiole } \\
\text { width } \\
(\mathrm{cm})\end{array}$ & $\begin{array}{c}\text { peti } \\
\text { ole } \\
\text { arm } \\
\text { ed }\end{array}$ & $\begin{array}{l}\text { no. of } \\
\text { segme } \\
\text { nts }\end{array}$ & $\begin{array}{c}\text { middle } \\
\text { segment } \\
\text { length }(\mathrm{cm})\end{array}$ & $\begin{array}{l}\text { segmen } \\
t \text { width } \\
\text { (cm) }\end{array}$ & $\begin{array}{c}\text { Segment } \\
\text { arrangement }\end{array}$ & $\begin{array}{c}\text { plicati } \\
\text { on }\end{array}$ \\
\hline $\begin{array}{l}\text { Acoelorraphe } \\
\text { wrightii }\end{array}$ & 1 & $\begin{array}{c}0.7 \text { to } \\
0.9\end{array}$ & Y & $\begin{array}{l}17 \text { to } \\
25\end{array}$ & 39 to 59 & $\begin{array}{l}1.5 \text { to } \\
2.1\end{array}$ & $\begin{array}{l}\text { Spreading, free } \\
\sim 50 \%\end{array}$ & $\begin{array}{l}\text { indupli } \\
\text { cate }\end{array}$ \\
\hline Brahea aculeata & 1,2 & 1.5 & Y & c. 40 & 56 & $\begin{array}{l}1.0 \text { to } \\
1.5\end{array}$ & $\begin{array}{l}\text { Spreading, free } \\
\geq 50 \%\end{array}$ & $\begin{array}{l}\text { indupli } \\
\text { cate }\end{array}$ \\
\hline $\begin{array}{l}\text { Rhapidophyllum } \\
\text { hystrix }\end{array}$ & 1,2 & $\begin{array}{c}0.5 \text { to } \\
0.7\end{array}$ & $\mathrm{~N}$ & 6 to 10 & 45 to 52 & $\begin{array}{l}2.4 \text { to } \\
3.8\end{array}$ & $\begin{array}{l}\text { Spreading, free } \\
>50 \%\end{array}$ & $\begin{array}{l}\text { redupli } \\
\text { cate }\end{array}$ \\
\hline Sabal etonia & 3 & $\begin{array}{l}1.1 \text { to } \\
1.8\end{array}$ & $\mathrm{~N}$ & $\begin{array}{c}25 \text { to } \\
50\end{array}$ & 35 to 64 & $\begin{array}{c}1.3 \text { to } \\
3.1\end{array}$ & Free $<50 \%$ & $\begin{array}{l}\text { indupli } \\
\text { cate }\end{array}$ \\
\hline Sabal minor & 2 & $\begin{array}{l}0.5 \text { to } \\
2.6\end{array}$ & $\mathrm{~N}$ & $\begin{array}{l}15 \text { to } \\
65\end{array}$ & 34 to 84 & $\begin{array}{c}1.4 \text { to } \\
3.7\end{array}$ & Free $>50 \%$ & $\begin{array}{l}\text { indupli } \\
\text { cate }\end{array}$ \\
\hline Sabal miamiensis & 3 & $\begin{array}{l}1.1 \text { to } \\
1.8\end{array}$ & $\mathrm{~N}$ & $\begin{array}{c}25 \text { to } \\
50\end{array}$ & 35 to 64 & $\begin{array}{l}1.3 \text { to } \\
3.1\end{array}$ & Free $>50 \%$ & $\begin{array}{l}\text { indupli } \\
\text { cate }\end{array}$ \\
\hline Sabal palmetto & 3 & $\begin{array}{l}0.5 \text { to } \\
2.6\end{array}$ & $\mathrm{~N}$ & $\begin{array}{l}15 \text { to } \\
65\end{array}$ & 34 to 84 & $\begin{array}{c}1.4 \text { to } \\
3.7\end{array}$ & Free $>50 \%$ & $\begin{array}{l}\text { indupli } \\
\text { cate }\end{array}$ \\
\hline Sabal mexicana & 3 & 1.5 to 3 & $\mathrm{~N}$ & $\begin{array}{c}35 \text { to } \\
70\end{array}$ & c. 85 & $\begin{array}{c}2.8 \text { to } \\
3.0\end{array}$ & Free $>50 \%$ & $\begin{array}{l}\text { indupli } \\
\text { cate }\end{array}$ \\
\hline Serenoa repens & 1 & $\begin{array}{l}0.3 \text { to } \\
0.6\end{array}$ & Y & $\begin{array}{l}10 \text { to } \\
24\end{array}$ & 17 to 35 & $\begin{array}{l}0.8 \text { to } \\
2.4\end{array}$ & $\begin{array}{l}\text { Spreading, free } \\
>50 \%\end{array}$ & $\begin{array}{l}\text { indupli } \\
\text { cate }\end{array}$ \\
\hline $\begin{array}{l}\text { Sabalites } \\
\text { geneseensis }(\mathrm{F})\end{array}$ & 2 & $\begin{array}{c}0.35 \text { to } \\
0.4\end{array}$ & $\mathrm{~N}$ & $\begin{array}{l}14 \text { to } \\
22\end{array}$ & $\begin{array}{c}>4.8 \text { to } \mathrm{c} . \\
12.7\end{array}$ & $\begin{array}{l}0.3 \text { to } \\
0.98\end{array}$ & Free $<50 \%$ & $\begin{array}{l}\text { indupli } \\
\text { cate }\end{array}$ \\
\hline $\begin{array}{l}\text { Costapalma } \\
\text { philipi }(\mathrm{F})\end{array}$ & 2 & 1.0 & $\mathrm{~N}$ & c. 35 & $\begin{array}{c}>23 \\
(50-60)\end{array}$ & $?$ & Free $<50 \%$ & $\begin{array}{l}\text { indupli } \\
\text { cate }\end{array}$ \\
\hline $\begin{array}{l}\text { Palmacites dorfi } \\
\text { (F) }\end{array}$ & 1 & 0.5 & $\mathrm{~N}$ & 30 & $>12$ & $\begin{array}{c}0.6 \text { to } \\
0.7\end{array}$ & $\begin{array}{c}\text { Spreading, free } \\
\sim 50 \%\end{array}$ & $\begin{array}{l}\text { indupli } \\
\text { cate }\end{array}$ \\
\hline
\end{tabular}


Table 2. Climate estimates for Genesee from leaf physiognomy (CLAMP using GRIDMet3brAZ, and MAP from LAA) with uncertainties (Yang et al. 2015; Wilf et al. 1998).

\begin{tabular}{cccccccccc} 
& $\begin{array}{c}M A T \\
\left({ }^{\circ} \mathrm{C}\right)\end{array}$ & $\begin{array}{c}\text { WMMT } \\
\left({ }^{\circ} \mathrm{C}\right)\end{array}$ & $\begin{array}{c}\text { CMMT } \\
\left({ }^{\circ} \mathrm{C}\right)\end{array}$ & $\begin{array}{c}\text { GROWSEAS } \\
(\text { months })\end{array}$ & $\begin{array}{c}\text { GSP } \\
(\mathrm{cm})\end{array}$ & $\begin{array}{c}\text { MAP } \\
(\mathrm{cm} / \mathrm{yr})\end{array}$ & $\begin{array}{c}\text { Three_WET } \\
(\mathrm{cm})\end{array}$ & $\begin{array}{c}\text { Three_DRY } \\
(\mathrm{cm})\end{array}$ & $\begin{array}{c}\text { RH } \\
(\%)\end{array}$ \\
\hline $\begin{array}{c}\text { Estimat } \\
\mathrm{e}(n= \\
28)\end{array}$ & 11.0 & 19.5 & 2.4 & 6.7 & 47.0 & 186 & 34.0 & 22.6 & 83.9 \\
$\pm \sigma$ & 2.1 & 2.5 & 3.4 & 1.1 & 32 & $\begin{array}{r}210 \\
+80,-56\end{array}$ & 22.9 & 5.9 & 8.6 \\
& & & & & & & & & \\
& & & & & & & & & \\
\hline
\end{tabular}


Figure 1. (A) Location of the Genesee Paleocene locality and known Paleocene records of Sabal or Sabalites. AB, Alberta; AK, Alaska; CO, Colorado; MT, Montana; NM, New Mexico; WA, Washington; WY, Wyoming. Data from sources cited in the text. (B) Map of Alberta showing Genesee locality (inset C), and the Munce's Hill (1), Joffre Bridge (2), and Gao Mine (3) Paleocene megaflora localities. (C) Google Earth image of the area around the Genesee locality showing the course of the North Saskatchewan River, and the location of the Genesee coal mine and Genesee fossil locality. Red outline is the Genesee Natural Area (Alberta Government, 2016).

Figure 2. Examples of Paleocene fan palms from Washington, Alaska, and Montana. (A) Specimen of Sabalites campbelli in outcrop of Bellingham Bay Mbr., Chuckanut Formation, Washington (G. Mustoe); rock hammer for scale. (B). Specimen of Sabalites cf. campbelli exposed on rock outcrop from the Late Paleocene to Eocene Chickaloon Formation showing costapalmate form (D. Sunderlin); arrow indicating presence of costa. Scale in $\mathrm{cm}$ at lower edge of card to left of fossil. (C) Holotype of Palmacites dorfi (syn. Thrinax dorfi) from the Fort Union Fm., Montana (Smithsonian Paleobiology Collection, image by Nathan Kitto; USNM PAL 167489). Scale bar $=2 \mathrm{~cm}$.

Figure 3. Paleocene palm leaf from the upper Scollard Formation, Alberta, identified here as Sabalites geneseensis sp. nov. (A) Holotype specimen (TMP 95.80.04 A) with the petiole present showing a narrow costa. Scale bar $=2 \mathrm{~cm}$. (B) Line drawing of holotype highlighting major detail of venation. Costa indicated by arrow. (C) Line drawing of inset area shown on (B), showing fine details of leaf venation, including zig-zag pattern transverse veins. Scale bar $=2 \mathrm{~mm}$. 
Figure 4. Additional specimens from the Royal Tyrrell Museum of Palaeontology fossil plant collection (TMP). (A) Counterpart of holotype specimen in Figure 3A showing base of leaf blade with narrow costa at arrow (TMP 95.80.04 B). (B) Referred very small specimen of $S$. geneseensis sp. nov. with the petiole present showing a narrow costa and prominent plication of the segments (TMP 95.80.01). (C \& D) Part and counterpart of referred specimen of $S$. geneseensis sp. nov. (TMP 95.80.03) lacking petiole or costa, but showing palmate pattern of leaf segments with some folding at base to left of image in D. (E) Referred specimen of $S$. geneseensis sp. nov. showing plicate segments, but lacking costa or petiole (TMP 95.80.02 B). Scale bar $=\mathrm{cm}$.

Figure 5. Speculative reconstructions of the Sabalites geneseensis sp. nov. plant. (A) Reconstructed as a palmetto similar to Sabal etonia or S. minor. (B) Reconstructed as a small, procumbent-stem palm similar to the extant Serenoa repens. 


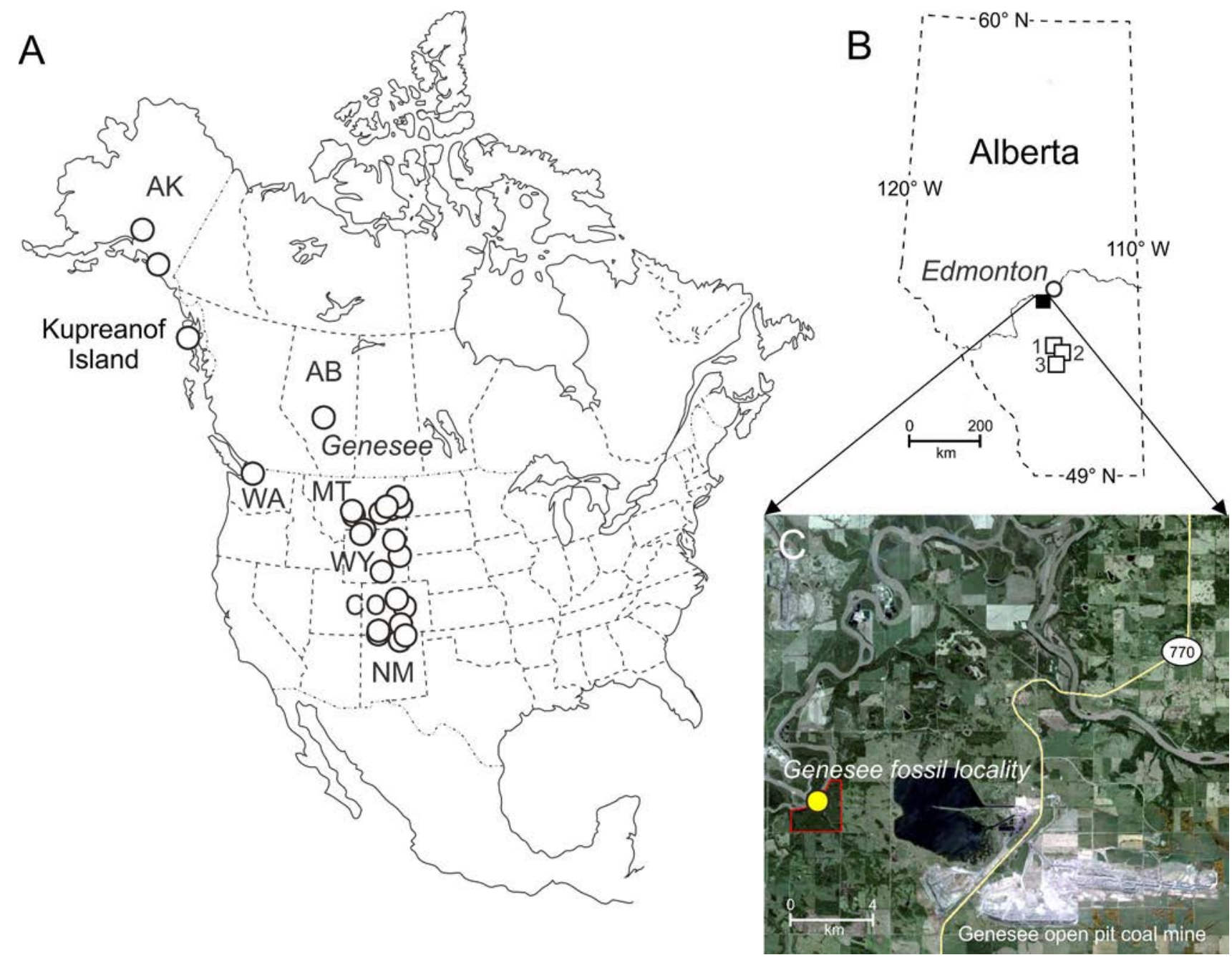




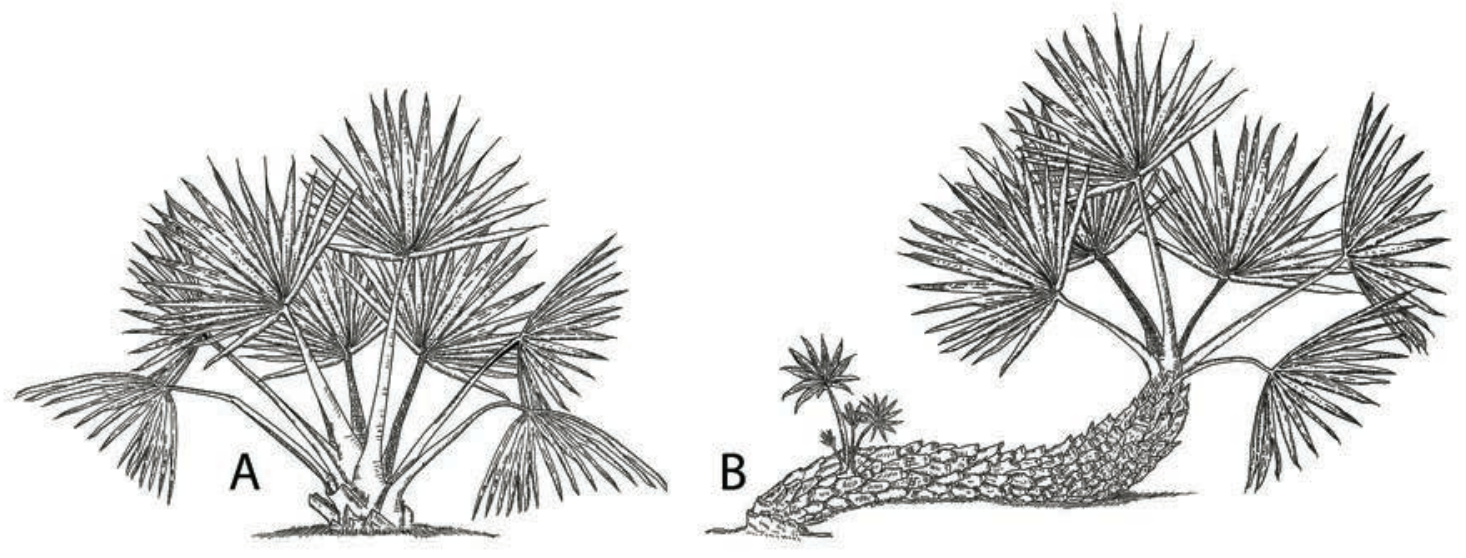




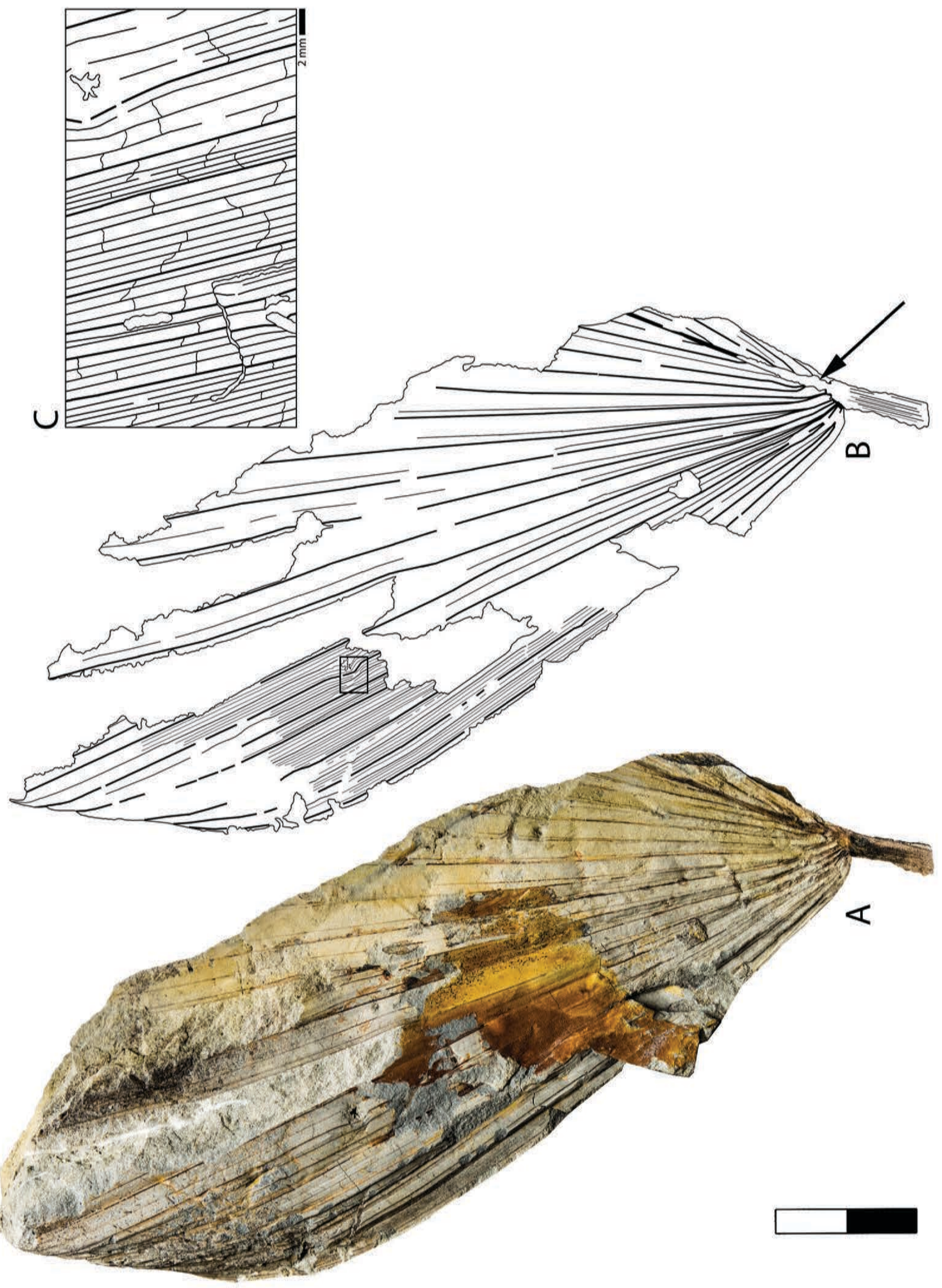




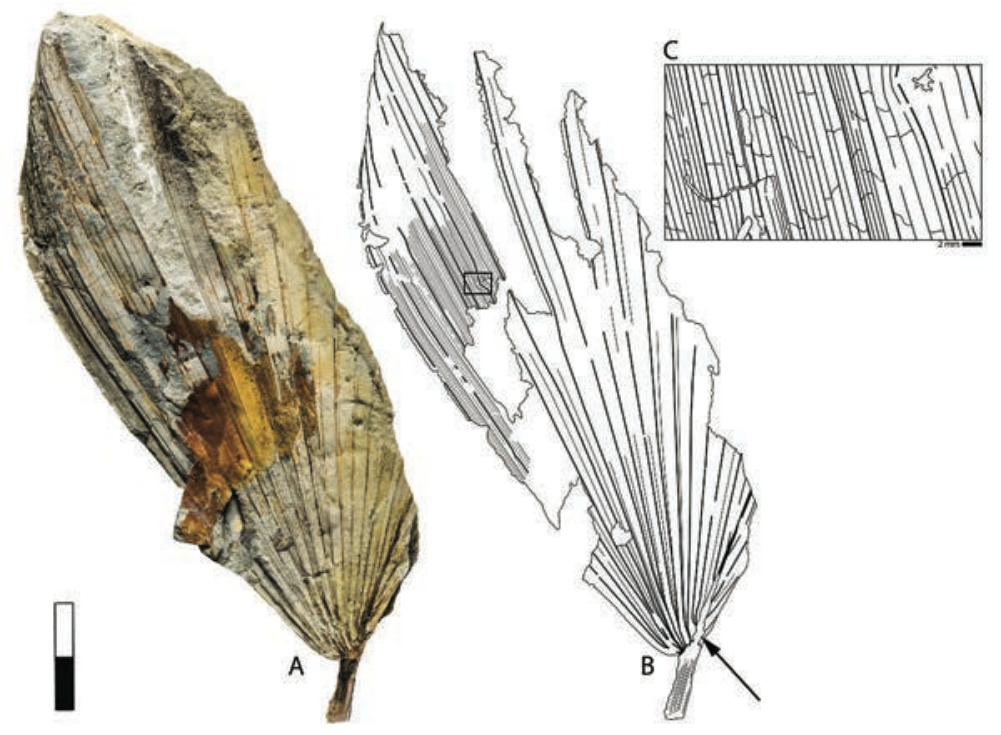




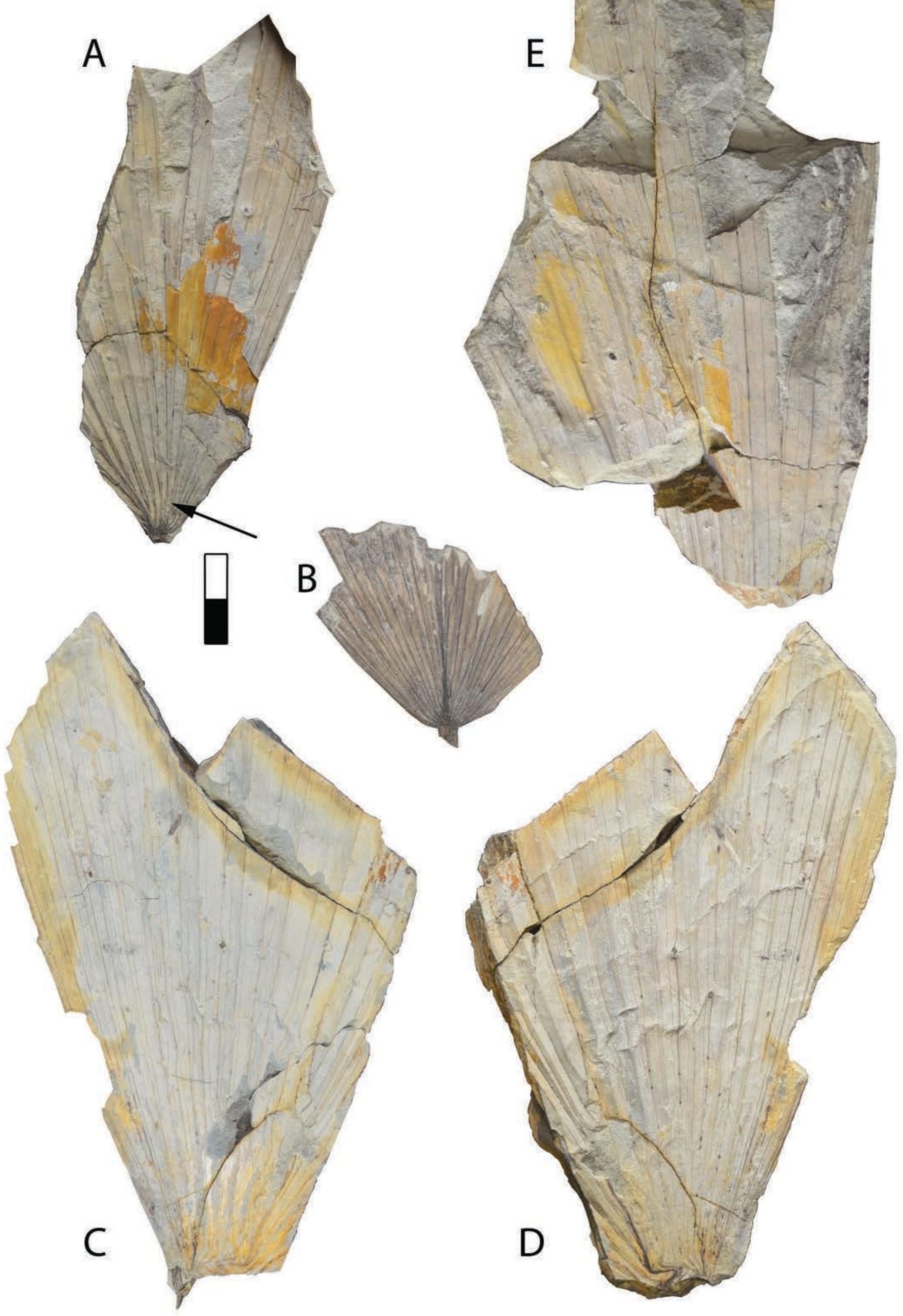




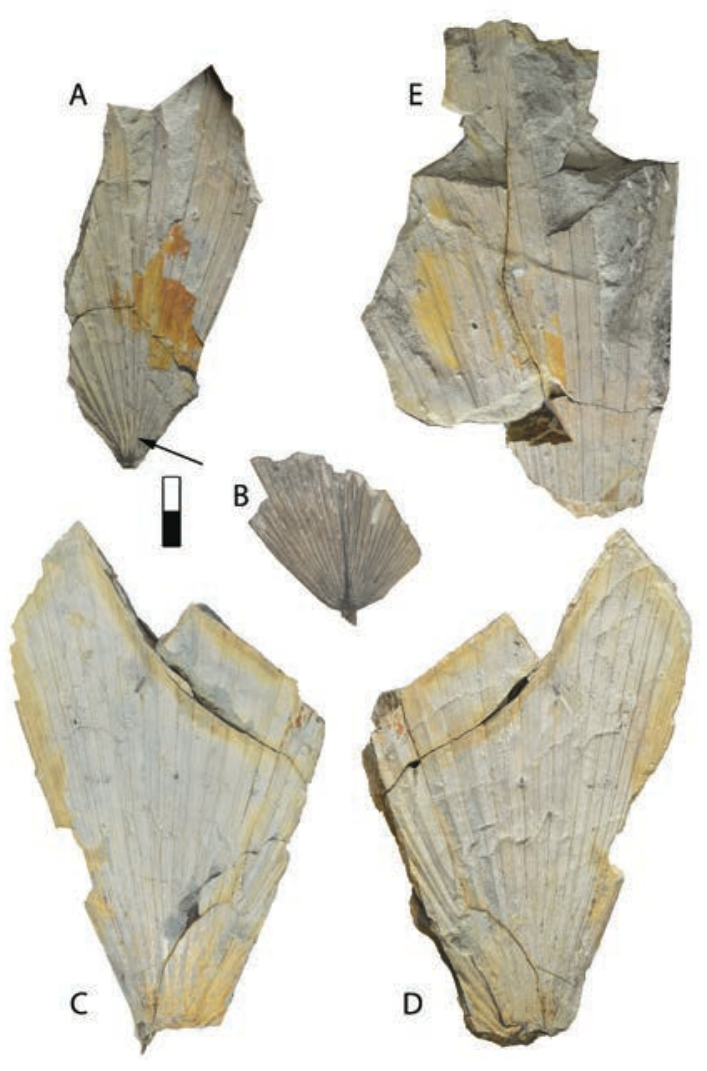



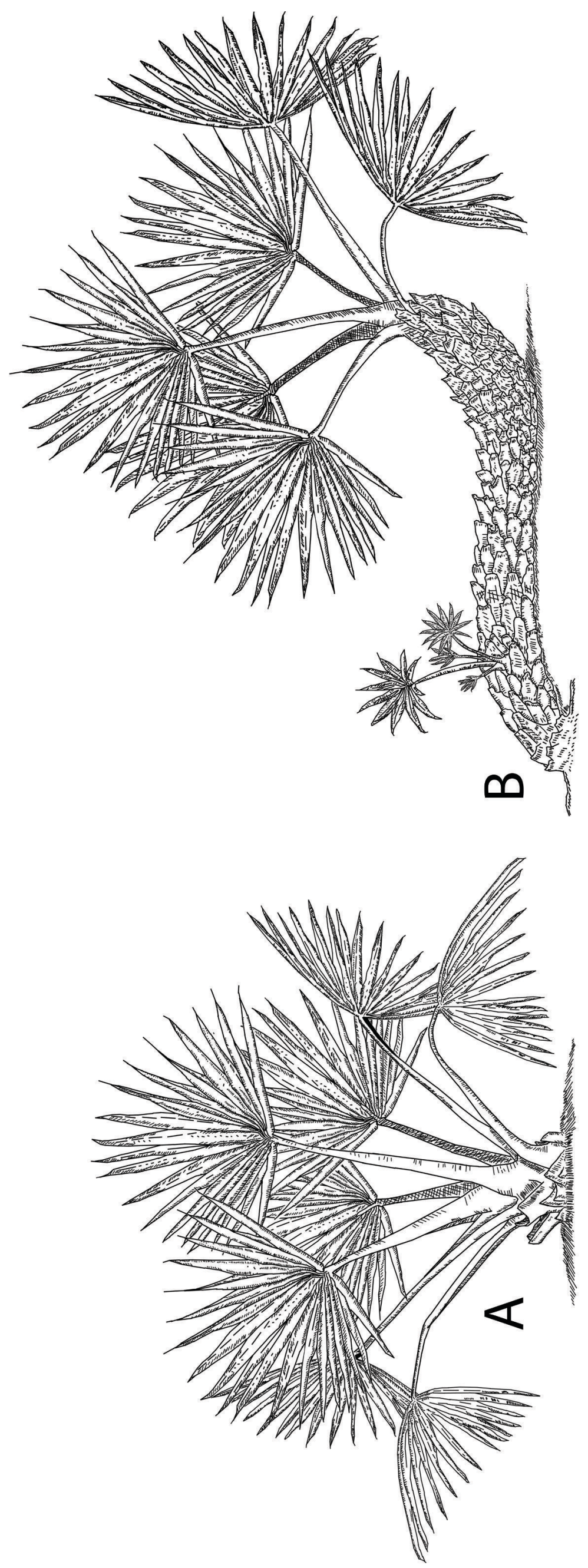